10.53116/pgaflr.2018.1.9

\title{
Macroeconomic Legal Trends in the EU11 Countries
}

\author{
László Vértesy*
}

\begin{abstract}
* László Vértesy, PhD jur. PhD œc. Associate Professor for Administrative Law and Finance at the National University of Public Service, Faculty of Public Administration in Hungary. Since 2005 he has been constantly teaching in higher education, presenting lectures, participating in conferences in Hungary and in other countries. His work encompasses a number of fields: in jurisprudence: administrative law (public administration, administrative procedure, efficiency and management, public tasks, good governance), financial law, banking and commercial law; and in economics: macroeconomics, financial sector, monetary and fiscal policy, business cycle, furthermore law and economics. (e-mail: vertesy.laszlo@uni-nke.hu)
\end{abstract}

\begin{abstract}
This contribution deals with the macroeconomic legal trends in the Eastern member states of the European Union, so called EU11: Bulgaria, Croatia, the Czech Republic, Estonia, Latvia, Lithuania, Hungary, Poland, Romania, Slovakia and Slovenia. The paper discusses the development from the 1990s to nowadays, emphasizing the initial changes and the consolidation after the financial crisis. Therefore, the fiscal policy bears a major attention: fiscal and budgetary stability, government debts, fiscal controls (auditing and independent fiscal councils), for a more comprehensive overview, some ports of the monetary policy will be examined: national banks and price stability. The main aim of the contribution is to confirm or disprove the hypothesis that there is any identifiable or verifiable correlation between the legislation and the macroeconomic trends: sustainable balanced budget and government debt, economic growth, inflation. The research is based on law and economics, especially law and finance methodology with quantitative analysis, because of the cross-discipline nature of the topic. The paper contains some comparative statistics to evaluate the certain results upon figures, because it is even important to match the legal provisions with the economic performance.
\end{abstract}

Keywords: llaw and finance; law-making; EU countries; macroeconomics; government debt; inflation; economic growth

\section{Introduction}

The main aims of the article are to summarise the economic and legal development of the eastern member states of the European Union. The terminology EU11 countries refer the Central, Eastern and Baltic European member states which accessed in 2004 and after: in 2004 the Czech Republic, Estonia, Latvia, Lithuania, Hungary, Poland, Slovenia, and the Slovak Republic; in 2007 Bulgaria, Romania; and in 2013 Croatia. In the recent years, numerous reforms related to public law and finance can be found. Therefore, it is interesting to demonstrate the close or loose relationships between the legislative and the macroeconomic trends, in order to find out how public finances are developing with or without legal background. Because of the fact that the EU11 countries are rule of law states, and particularly even the prescriptions of the Maastricht criteria and the Stability 


- a national budget deficit at or below 3 percent of the gross domestic product (GDP);

- national public debt not exceeding 60 percent of the gross domestic product, a country with a higher level of debt can still adopt the euro provided its debt level is falling steadily;

- long-term interest rates should be no more than two percentage points above the rate of the three EU countries with the lowest inflation over the previous year;

- the national currency is required to enter the ERM 2 exchange rate mechanism two years prior to entry.

At the national level, after the financial crisis, a relatively new trend can be identified: finances increasingly become enfolded even into the level of constitutionalism. In addition to some general and common fiscal provisions (economic system, budgeting, taxation, state audit, central bank, national currency, national wealth or assets) in some of the EU11 countries, a separate chapter deals with macroeconomics and public finances: Hungary (Chapter: Public Finances, Articles 36-44), Lithuania (Chapter XI Finances and the State Budget), Poland (Chapter X. Public Finances), Slovenia (Part VI. Public Finance). These sections contain more and more detailed regulations on a balanced budget and interim, temporary rules, budgetary settlements and accounting, state audit and controls, the decisions or the management of the general government debt, central bank or the state treasury.

\section{Fiscal Stability}

Two criterions of the Maastricht criteria focus on fiscal issues: an annual deficit below 3\% and a general government debt below 60\% of the GDP. The Stability and Growth Pact (SGP), which was introduced as a framework to ensure price stability and fiscal responsibility, adopted identical limits for governments budget deficit and debt as the convergence criteria. Due to the fact that several countries did not exercise a sufficient level of fiscal responsibility during the first ten years of the euro's lifetime, two major SGP reforms were introduced. The first reform was the Sixpack which entered into force in December 2011, and relates to the following regulations and guidelines for fiscal and monetary policy: ${ }^{7}$

- Regulation 1173/2011: On the effective enforcement of budgetary surveillance in the euro area;

- Regulation 1174/2011: On enforcement action to correct excessive macroeconomic imbalances in the euro area;

- Regulation 1175/2011 amending Regulation 1466/97: On the strengthening of the surveillance of budgetary positions and the surveillance and coordination of economic policies;

- Regulation 1176/2011: On the prevention and correction of macroeconomic imbalances; 
- Regulation 1177/2011 amending Regulation 1467/97: On speeding up and clarifying the implementation of the excessive deficit procedure;

- Directive 2011/85/EU: On requirements for budgetary frameworks of the Member States.

Later, in January 2013, it was followed by the even more ambitious Fiscal Compact, which was signed by the EU member states. This Twopack contains two regulations to reform a part of the Stability and Growth Pact for Eurozone member states:

Regulation 473/2013: On common provisions for monitoring and assessing draft budgetary plans and ensuring the correction of excessive deficit of the Member States in the euro area,

Regulation 472/2013: On the strengthening of economic and budgetary surveillance of Member States in the euro area experiencing or threatened by serious difficulties with respect to their financial stability.

\subsection{Budgetary Stability and Government Debt}

The budgeting follows a historically and internationally accepted concept. The legislature assesses - by an act - the central budget and with a separate action adopts its implementation, final account for each year. The executive is responsible for submitting the proposal, and authorised (by the legislative adoption of the act on the central budget) to implement it, by collecting the revenues and disbursing the expenditures. The state audit of the government budget and the expenditures is an essential control element in public finances.

The constitutions establish a separate public organ, which is independent, and/or subordinated to the legislature (parliament or the national assembly), strengthens the system of checks and balances, and its president or the chief accountant elected for a longer term than the parliamentary election: 6-12 years. The naming is different, the most common expressions are the following: supreme, state audit institution, chamber, committee office or court, furthermore instead of audit control can be found, it reflects the auditors or accounts. The list of EU11 countries supreme audit institutions: Сметна палата (Bulgaria), Državni ured za reviziju (Croatia), Nejvyšší kontrolní úřad (the Czech Republic), Riigikontroll (Estonia), Valsts kontrole (Latvia), Valstybës kontrolë (Lithuania), Állami Számvevőszék (Hungary), Najwyższa Izba Kontroli (Poland), Curtea de Conturi (Romania), Računsko sodišče (Slovenia), Najvy̌šš́ kontrolný úrad (Slovakia).

After the Mortgage-Debt Financial Crisis and the European Debt Crisis, it can be observed that the principle of balanced, transparent and sustainable budget management became more and more important. ${ }^{8}$ Therefore, the general government debt and the deficit are the crucial areas. 
Table 2.

General government deficit/surplus (\% GDP)

\begin{tabular}{|l|r|r|r|r|r|r|r|}
\hline & 2005 & 2008 & 2009 & 2010 & 2013 & 2015 & 2017 \\
\hline BGR & 1.8 & 1.6 & -4.1 & -3.1 & -0.4 & -1.6 & 0.9 \\
\hline HRV & -3.4 & -2.8 & -6 & -6.5 & -5.3 & -3.4 & 0.8 \\
\hline CZE & -2.2 & -2 & -5.5 & -4.2 & -1.2 & -0.6 & 1.6 \\
\hline EST & 2.9 & -2.7 & -2.2 & 0.2 & -0.2 & 0.1 & -0.3 \\
\hline HUN & -9.3 & -3.7 & -4.5 & -4.5 & -2.6 & -1.9 & -2 \\
\hline LVA & -0.5 & -4.2 & -9.1 & -8.7 & -1.2 & -1.4 & -0.5 \\
\hline LTU & -0.3 & -3.1 & -9.1 & -6.9 & -2.6 & -0.2 & 0.5 \\
\hline POL & -3.6 & -3.6 & -7.3 & -7.3 & -4.1 & -2.6 & -1.7 \\
\hline ROM & -2.1 & -5.4 & -9.2 & -6.9 & -2.1 & -0.8 & -2.9 \\
\hline SVK & -3.6 & -2.4 & -7.8 & -7.5 & -2.7 & -2.7 & -1 \\
\hline SVN & -1.2 & -1.4 & -5.8 & -5.6 & -14.7 & -2.9 & 0 \\
\hline Avr. & -2.0 & -2.7 & -6.4 & -5.5 & -3.4 & -1.6 & -0.4 \\
\hline
\end{tabular}

Source: Own compilation based on Eurostat: General government deficit/surplus, 2018

The balance of the budget is the surplus (sufficit) or the deficit, which essentially compromises the change of the government debt.

Table 3.

General government gross debt (\% GDP)

\begin{tabular}{|l|r|r|r|r|r|r|r|r|}
\hline & 2000 & 2005 & 2008 & 2009 & 2010 & 2013 & 2015 & 2017 \\
\hline BGR & 71.2 & 26.8 & 13 & 13.7 & 15.3 & 17 & 26 & 25.4 \\
\hline HRV & 35.5 & 41.1 & 39 & 48.3 & 57.3 & 80.5 & 83.8 & 78 \\
\hline CZE & 17 & 27.9 & 28.3 & 33.6 & 37.4 & 44.9 & 40 & 34.6 \\
\hline EST & 5.1 & 4.5 & 4.5 & 7 & 6.6 & 10.2 & 10 & 9 \\
\hline HUN & 55.3 & 60.5 & 71.6 & 77.8 & 80.2 & 77.1 & 76.7 & 73.6 \\
\hline LVA & 12.1 & 11.4 & 18.2 & 35.8 & 46.8 & 39 & 36.8 & 40.1 \\
\hline LTU & 23.5 & 17.6 & 14.6 & 28 & 36.2 & 38.8 & 42.6 & 39.7 \\
\hline POL & 36.5 & 46.4 & 46.3 & 49.4 & 53.1 & 55.7 & 51.1 & 50.6 \\
\hline ROM & 22.4 & 15.7 & 12.4 & 22.1 & 29.7 & 37.5 & 37.7 & 35 \\
\hline SVK & 49.6 & 34.1 & 28.5 & 36.3 & 41.2 & 54.7 & 52.3 & 50.9 \\
\hline SVN & 25.9 & 26.3 & 21.8 & 34.6 & 38.4 & 70.4 & 82.6 & 73.6 \\
\hline Avr. & 32.2 & 28.4 & 27.1 & 35.1 & 40.2 & 47.8 & 49.1 & 46.4 \\
\hline
\end{tabular}

Source: Own compilation based on Eurostat: General government gross debt, 2018

Nonetheless, the average of the government debt in the EU11 countries is nearly $46 \%$, but the deviation is great, because the lowest figure is $9 \%$ (Estonia), but the highest is $78 \%$ (Croatia). Only three countries are affected by high government debt: Croatia, Hungary and Slovenia (over $70 \%$ of the GDP), while Slovakia and Poland fulfil the Maastricht 
requirement, but only with $10 \%$ below the threshold. Nevertheless, there is no excessive deficit procedure against one of the Member States. The trend shows that the sovereign debt ratio to the GDP in most of the countries has been rising, and after the financial crisis, and the introduction of the national provisions and the implementation of the Stability and Growth Pact, ${ }^{9}$ a general slight decrease can be observed in the countries with higher debt ratio to the GDP than it is stated in the Maastricht criteria (Croatia, Hungary, Slovenia). On the one hand, the excessive deficit procedure, ${ }^{10}$ and the possibility of fining proved to be effective, but even the national legislation can coerce the state for relevant efforts.

In Lithuania, the decisions concerning the State loan and other basic property liabilities of the State shall be adopted by the Seimas on the proposal of the Government. ${ }^{11}$ In Poland it is neither permissible to contract loans, nor provide guarantees and financial sureties which would engender a national public debt exceeding three-fifths of the value of the annual gross domestic product. ${ }^{12}$ Hungary has the strictest constitutional rule on budgeting and government debt, since that the National Assembly may not adopt an Act on the central budget as a result of which state debt would exceed half of the GDP, and as long as this condition is not satisfied, the National Assembly may only adopt a central budget which provides for state debt reduction in proportion to the GDP, and no such borrowing may be contracted and no such financial commitment may be undertaken. ${ }^{13}$ The public financial consolidation is proven to be more important than fundamental rights and constitutional guarantees, because as a further restriction, as long as the state debt exceeds half of the GDP, the Constitutional Court may review the Acts on the central budget and central taxes for conformity with the Fundamental Law exclusively in connection with life and human dignity, protection of personal data, to freedom of thought, conscience and religion, and it may annul these acts only for the violation of these rights. The results are obvious: slight decrease (7\%) of the government debt ratio, and the excessive deficit procedure was abrogated, shortly after the adoption of the Fundamental Law (2011). ${ }^{14}$ It can be said that without this restriction and limitation, the previous governments originated an excessive state debt by borrowing huge credits and loans. But it has to be noted that the same and higher decrease can be observed without such a provision (e.g. the Czech Republic, Latvia, Slovenia), and others can maintain on a low level (Estonia).

The macroeconomic stabilisation involved lower levels in hierarchy of sources of law: acts, cardinal or organic acts, strategic government decisions etc., for example in Hungary Act CXCIV of 2011 on the Economic Stability was adopted. In some other countries (Poland, Slovenia, Estonia) the acts on public finances define the restrictions. 
Table 4.

Structural primary balance and fiscal efforts

\begin{tabular}{|l|r|r|r|r|r|r|r|r|r|}
\hline & \multicolumn{4}{|c|}{ Structural primary balance (\% of GDP) } & \multicolumn{4}{c|}{ Consolidation effort } \\
\hline & 2012 & \multicolumn{1}{|c|}{2013} & \multicolumn{1}{|c|}{2014} & \multicolumn{1}{|c|}{2015} & \multicolumn{1}{c|}{2016} & \multicolumn{1}{c|}{2013} & 2014 & \multicolumn{1}{c|}{2015} & 2016 \\
\hline BGR & 0.70 & 0.40 & 0.00 & 0.10 & 0.00 & -0.30 & -0.40 & 0.10 & -0.10 \\
\hline CZE & 0.10 & 0.00 & -0.30 & -0.50 & -1.00 & -0.10 & -0.30 & -0.20 & -0.50 \\
\hline EST & 0.30 & -0.20 & 0.50 & 0.50 & 1.00 & -0.50 & 0.70 & 0.00 & 0.50 \\
\hline HUN & 3.50 & 3.10 & 2.10 & 1.70 & 1.60 & -0.40 & -1.00 & -0.40 & -0.10 \\
\hline LVA & 0.90 & 0.00 & -0.10 & -0.60 & -0.90 & -0.90 & -0.10 & -0.50 & -0.30 \\
\hline LTU & -1.90 & -0.80 & -0.10 & 0.60 & 1.30 & 1.10 & 0.70 & 0.70 & 0.70 \\
\hline POL & -0.80 & 0.00 & 0.20 & 0.30 & 0.90 & 0.80 & 0.20 & 0.10 & 0.60 \\
\hline ROM & -1.00 & 0.20 & 0.60 & 0.70 & 0.70 & 1.20 & 0.40 & 0.10 & 0.00 \\
\hline SVK & -2.20 & -1.00 & -0.50 & 0.20 & 0.60 & 1.20 & 0.50 & 0.70 & 0.40 \\
\hline SVN & -0.70 & 0.10 & 1.50 & 1.30 & 1.50 & 0.80 & 1.40 & -0.20 & 0.20 \\
\hline Avr. & -0.11 & 0.18 & 0.39 & 0.43 & 0.57 & 0.29 & 0.21 & 0.04 & 0.14 \\
\hline
\end{tabular}

Source: Own compilation based on Berti-Castro-Salto: Effects of fiscal consolidation envisaged in the 2013 Stability and Convergence Programmes on public debt dynamics in EU Member States. 13.

In the interest of fiscal discipline, many countries have reduced the budget deficit, or maintain on a low level, in order to meet the Maastricht deficit criterion, furthermore to reduce the general government deficit ratio. According to the figures, the highest pressure was on the Hungarian government. Even the Slovenian public debt ratio is high, but it has a balanced budget. After the consolidation, a significant proportion of the EU11 countries realized a sufficit in the budget for one or more years.

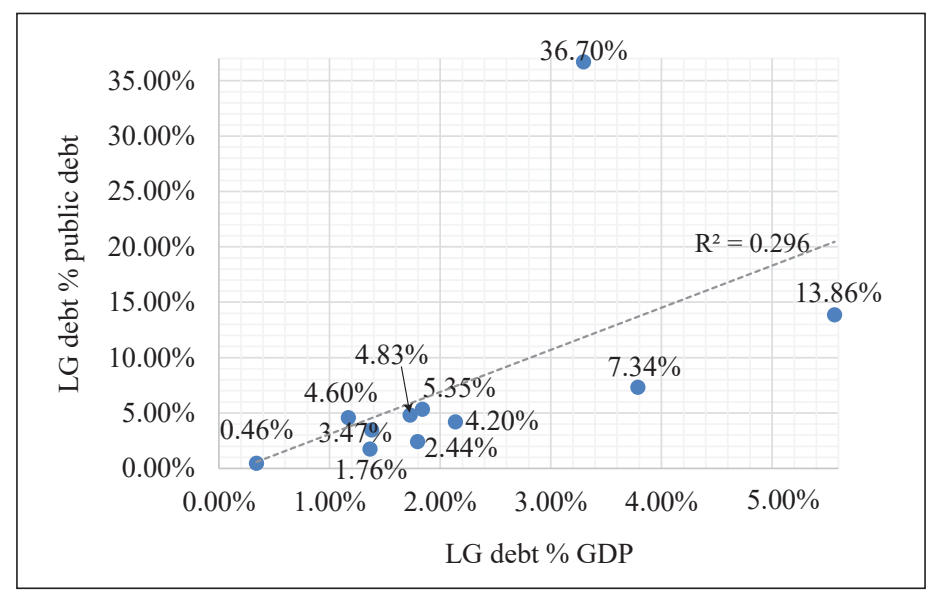

Figure 1 .

Local government debts (\% GDP and \% Public Debt)

Source: Own compilation based on Eurostat Government finance statistics [gov_10dd_logd], [gov_10dd_cgd] 
In some countries, since the local government debt needs to be calculated into the general government debt, some state introduced different types of limitations for them. ${ }^{15}$ In Estonia, limits for local debt were introduced from 2009 to 2012. According to the Financial Management of Local Authorities Act of 2011, ${ }^{16}$ the debt ceiling for local governments ranges from $60 \%$ to $100 \%$ of the current year operational revenues (depending on the municipality self-financing capacity). ${ }^{17}$ In Latvia local governments can only carry out long-term borrowing to finance investment projects (golden rule). Loans must be contracted with the State Treasury or within specific funding programmes, or borrowing from another institution must be justified and authorised by the Ministry of Finance. The borrowing in a given year cannot exceed $20 \%$ of current revenues. ${ }^{18}$ In Poland the Public Finance Act stipulates the sum of local loan instalments and interest payments must not exceed $15 \%$ of total debt, ${ }^{19}$ and later in 2014 it was declared, that the debt of local governments should not exceed $60 \%$ of GDP. ${ }^{20}$ In Hungary, the Fundamental law states, that in order to preserve a balanced budget, for any borrowing or for other undertaking of commitments by local governments to the extent determined in the stability act, certain conditions and/or the consent of the Government are required. ${ }^{21}$ Between 2011 and 2014 a comprehensive consolidation was carried out in four phases ${ }^{22}$ by the central government, while the local debts were overtaken by the government in amount of $€ 4.56$ billion (HUF 1,369 billion), ${ }^{23}$ which was $2.78 \%$ of GDP and $5.54 \%$ of the public debt. In Slovenia local government borrowing rights are regulated by the Public Finance Act (1999) and the Financing of Municipalities Act (2006), ${ }^{24}$ which stipulate, that the municipalities have the right to borrow to finance certain types of investment projects (golden rule), but they need prior consent of the Ministry of Finance. In the Czech Republic, within the new fiscal framework, the law requires that the level of local government gross debt remains below $60 \%$ of a four-year average of revenues. The bond issuance must be approved by the Ministry of Finance. ${ }^{25}$

\subsection{Independent Fiscal Council}

In some cases, in the order of the sustainable fiscality an advisory board involved in the budgetary procedure, by examining the feasibility of the central budget and taking part in the preparation, or the right of veto granted. The Fiscal Council of Croatia has, for example, a high degree of leverage. According to the so-called two-pack, ${ }^{26}$ euro area countries should have an independent body in place, such as a fiscal council, which is in charge of monitoring compliance with numerical fiscal rules and, where appropriate, assessing the need to activate the correction mechanism foreseen under the Fiscal Compact. ${ }^{27}$ The deadline for setting up a fiscal council was October 2013. ${ }^{28}$

The independent fiscal councils were established by the legislator - under different expressions - in Bulgaria (Фискален съвет на Бъмгария, Fiscal Council, 2015), Croatia (Odborza Fiskalnu Politiku, Fiscal Policy Committee, 2013), Estonia (Eelarvenóukogu, Fiscal Council, 2014), Latvia (Fiskālās disciplīnas padome, Fiscal Discipline Council, 2013), Lithuania (Lietuvos Respublikos valstybès kontrolè, National Audit Office - Budget Policy Monitoring Department, 2014), Hungary (Költségvetési Tanács, Budget Council, 
2008), Romania (Consiliul Fiscal, Fiscal Council, 2010), Slovenia (Urad RS Slovenije za makroekonomske analize in razvoj, Fiscal Council, 2015 and Institute of Macroeconomic Analysis and Development, 1995), Slovakia (Rada pre rozpočtovú zodpovednost', Council for Budget Responsibility, 2012). ${ }^{29}$ In Poland no fiscal council was founded.

Most of them are members of the Network of the EU Independent Fiscal Institutions (EU IFIs). ${ }^{30}$ The roles and members are different, but generally the effectiveness of fiscal councils will largely depend on whether they are independent from political interference and whether they have functional autonomy. This is even based by a more important law source, for example in Slovenia the Fiscal Council was established by the implementation of the amendment of the Constitution. ${ }^{31}$ In Romania, the Economic and Social Council is an advisory body of the Parliament and Government, in the specialised fields stated by the organic law for its establishment, organisation, and functioning, ${ }^{32}$ in Hungary the Budget Council can be found in the Fundamental law. ${ }^{33}$ Only in Latvia and Slovenia are respective macroeconomic forecasts produced by fiscal councils. ${ }^{34}$ Budgetary projections, which are produced in all countries by the government, are only scrutinised by an independent body for endorsement in Romania and Slovakia. ${ }^{35}$ In most countries the fiscal council members are academics or experts outside of the government, and their staff is mostly recruited on the basis of competence and experience. ${ }^{36}$ Although the members of the Hungarian Budget Council are the President of the Budget Council, the President of the National Bank of Hungary and the President of the State Audit Office, which may call into question the independence of the monetary policy and the audit.

It can be stated, that after the introduction - besides the relevant legal provisions on fiscal stability - the macroeconomic figures slightly moved to a better direction. The correlation is uncountable, because of the various and numerous indicators, but the observation raises the attention on the importance and the raison d'être of the independent fiscal councils.

\section{Price Stability}

The other main part of public finances is monetary policy. The central banks are public institutions which possess the monopoly on managing and implementing the monetary policy of a state or federation. Generally, the constitutions contain the central bank and often the national currency.

The functions of the central banks are the same, but the naming can be different, e.g. national bank: Бъмгарска народна банка, (Bulgaria) Hrvatska narodna banka (Croatia), Česká národní banka (Czech Republic), Magyar Nemzeti Bank (Hungary), Narodowy Bank Polski (Poland), Banca Națională a României (Romania), Národná Banka Slovenska (Slovakia); or bank of a country: Eesti Pank (Estonia), Latvijas Banka (Latvia), Lietuvos Bankas (Lithuania), Banka Slovenije (Slovenia). The content of the constitutional provisions is brief and quite different, the details can be found in separate (cardinal or organic) acts, statutes. Besides the monetary policy some central bank even performs the supervision of the financial intermediary system (the Czech Republic, Hungary, Lithuania, Slovakia). The legal, goal, operational and management independences are granted by 
different ways. The governor or the president of the central bank is appointed by the President (e.g. Hungary) or elected by the Parliament (e.g. Poland) for a longer term than the parliamentary cycle (five or six years). The monetary decisions lay with a monetary committee or governing council. In accordance with the independence and the sustainable government debt management, the principle of prohibition of monetary financing declares that overdraft facilities or any other type of credit facility with the European Central Bank or with the central banks of the Member States in favour of Union institutions, bodies, offices or agencies, central governments, regional, local or other public authorities, other bodies governed by public law, or public undertakings of Member States shall be prohibited, as shall the purchase directly from them by the European Central Bank or national central banks of debt instruments. ${ }^{37}$

In case of some EU11 countries, the national currency is not relevant yet, because they have already joined to the eurozone, therefore they use the common currency: Estonia (2011), Latvia (2014), Lithuania (2015), Slovakia (2009), Slovenia (2007). As it was read in the newspapers, ${ }^{38}$ the debt crisis in the eurozone caused that Poland and the Czech Republic rethought their view of deeper monetary integration in 2010. (In March 2018, the governors of the Polish central declared its commitment to joining the eurozone.) The non-euro members are not in ERM II, but obliged to join the eurozone on meeting convergence criteria. The constitutions determine the national currency: the Czech koruna, the Hungarian forint, the Polish złoty, the Romanian leu, but two countries do not declare the legal tender: Bulgaria (lev) and Croatia (kuna).

\subsection{Inflation}

There are no legal prescriptions on inflation in the examined countries legal system, but it is also important for the EU11 to comply with the Maastricht criterion: inflation of no more than 1.5 percentage points above the average rate of the three EU member states with the lowest inflation over the previous year. The inflation is the rate at which a sustained increase in the general price level of goods and services in an economy over a period of time, and consequently, the purchasing power of the currency is falling. ${ }^{39}$ The inflation rate is widely calculated by calculating the movement or change in a price index, usually the consumer price index (CPI). ${ }^{40}$

Table 5.

Annual inflation ratio (\%)

\begin{tabular}{|l|c|c|c|c|c|c|c|c|c|}
\hline & 1990 & 1995 & 2000 & 2005 & 2008 & 2009 & 2010 & 2015 & 2016 \\
\hline BGR & 23.8 & 62.05 & 10.32 & 5.04 & 12.35 & 2.75 & 2.44 & -0.10 & -0.8 \\
\hline HRV & 500 & 3.95 & 4.61 & 3.32 & 6.08 & 2.38 & 1.03 & -0.46 & -1.1 \\
\hline CZE &.. & 9.17 & 3.90 & 1.85 & 6.35 & 1.04 & 1.41 & 0.34 & 0.6 \\
\hline EST &.. & 28.78 & 4.02 & 4.09 & 10.37 & -0.08 & 2.98 & -0.46 & 0.1 \\
\hline HUN & 28.97 & 28.30 & 9.78 & 3.55 & 6.07 & 4.21 & 4.88 & -0.07 & 0.4 \\
\hline
\end{tabular}




\begin{tabular}{|l|c|c|c|c|c|c|c|c|c|}
\hline & 1990 & 1995 & 2000 & 2005 & 2008 & 2009 & 2010 & 2015 & 2016 \\
\hline LVA &.. & 24.98 & 2.65 & 6.72 & 15.43 & 3.47 & -1.07 & 0.20 & 0.1 \\
\hline LTU &.. & 39.66 & 1.01 & 2.64 & 10.93 & 4.45 & 1.32 & -0.88 & 0.9 \\
\hline POL & 555 & 28.07 & 10.06 & 2.11 & 4.35 & 3.83 & 2.71 & -0.99 & -0.6 \\
\hline ROU &.. & 32.24 & 45.67 & 8.99 & 7.85 & 5.59 & 6.09 & -0.59 & -1.5 \\
\hline SVK &.. & 9.89 & 12.04 & 2.71 & 4.60 & 1.62 & 0.96 & -0.33 & -0.5 \\
\hline SVN &.. & 13.46 & 8.88 & 2.48 & 5.65 & 0.86 & 1.84 & -0.52 & -0.1 \\
\hline Avr. &.. & 25.51 & 10.27 & 3.95 & 8.18 & 2.74 & 2.23 & -0.35 & -0.23 \\
\hline
\end{tabular}

Source: Own compilation based on World Bank: DataBank - World Development Indicators, 2018

In the early 1990s, due to the political changes above-mentioned almost in all the presented countries, there was a double-digit, in some cases a three-digit inflation. The artificial prices - kept by the government in the planned economy - suddenly went out of control, and the constituent governments for the first time did not know how to handle this. The inflation rate, in the examined area, relatively quickly dropped to below $5 \%$ by 2000 , except Romania. The economies of this decade - similar to the previous one - show a moderate inflation. As a new phenomenon, a slight negative inflation (deflation) appeared in this decade in several countries (Croatia, Estonia, Hungary, Poland, Romania, Slovakia and Slovenia). The main reasons for this is that the world market prices of raw materials greatly fell (particularly in the case of crude oil), the euro exchange rate changed, or because of sluggish corporate investments.

\section{Conclusion}

The common attribute of the EU11 countries is that all of them have experiences about socialism, but nevertheless, the beginning of the 1990s was just roughly the same. For some of them becoming independent was the major challenge, while others needed to face with poverty and deep dictatorship also. Economically, parallel with the political changes, and the democratic transition, - as a rule of law states - the previous command economies were transformed via the legislation into market economies, and set up or renewed the major macroeconomic factors: budgetary rules, national audit, national currency, central bank. Generally, they shortly encountered the following problems: high inflation, high unemployment, low economic growth and high government debt. By 2000 these economies were stabilised, and sooner or later between 2004 and 2013 all of them joined the European Union. New macroeconomic requirements have arisen for them; the Maastricht criteria became obligatory. Later the Stability and Growth Pact set stricter rules through national legislation by implementing e.g. the regulations and directives of the Sixpack, because the financial crisis was a shocking milestone not just for the EU11, but for the other member states. 
Unfortunately, clear and verifiable correlation between the macroeconomic development and the legislation cannot be calculated, since the multitude of the factor and indicators. Not only the legislators, but even the law applicators, the executive branch contributed to the positive results. Only three countries are affected by high government debt: Croatia, Hungary and Slovenia (over 70\% of the GDP), while Slovakia and Poland fulfil the Maastricht requirement but only with $10 \%$ below the threshold. Nevertheless, there is no excessive deficit procedure against one of the Member States. The balances of the central budget are lower than $3 \%$ of the GDP, sometimes change to surplus (sufficit). For the budgetary stability some countries introduced different restrictions, particularly on government borrowings, and adopted limits on the financial autonomy of the local governments. All the EU11 countries founded - under different naming - independent fiscal council, except Poland. In monetary policy the differences based on the eurozone, Estonia, Latvia, Lithuania, Slovakia, Slovenia use the common currency. The economies of this decade - similar to the previous one - show a moderate inflation. As a new phenomenon, a slight negative inflation (deflation) appeared in this decade in several countries (Croatia, Estonia, Hungary, Poland, Romania, Slovakia and Slovenia), which demonstrates sensitivity regarding international developments. 


\section{References}

1 For summary, see Gerhard Schnyder, The Law and Finance School: What Concept of Law? (King's College London, 2016). http://dx.doi.org/10.2139/ssrn.2859950

2 In Hungary, the former constitution (Act XX of 1949, amended in 1989) contained the social market economy in the Preamble, but in the text, Article 9 mentioned only the market economy. According to the interpretation of the Constitutional Court, the preamble is not obligatory for the state organs, therefore the economy is just market economy without any attribute, and the social market economy is just a state goal. 33/1993. (I. 28.) AB resolution, ABH 1993, 247, 249.

3 Constitution of Slovakia, Article 55 (1) The economy of the Slovak Republic is based on the principles of a socially and ecologically oriented market economy.

4 Fundamental Law of Hungary, Article M (1) The economy of Hungary shall be based on work which creates value, and on freedom of enterprise.

5 Tim Callen, Gross Domestic Product: An Economy's All (International Monetary Fund, 2012).

6 The provisions are based on Article 140 (ex-article 121.1) of the Treaty on the Functioning of the European Union and in the relevant Protocols

7 "Package of six legislative proposals." Hungarian Presidency of the Council of the European Union. April 2011. Retrieved 11 May 2013.

8 Katia Berti, Matteo Salto, Matthieu Lequien, An early-detection index of fiscal stress for EU countries. European Economy Economic Paper No. 475. 2012. and Francesco Caprioli, Sandro Momigliano, The macroeconomic effects of fiscal policy shocks during good and bad times, (mimeo. 2012). https://doi.org/10.2765/28160

9 Jocelyn Boussard, Francisco de Castro, Matteo Salto, Fiscal Multipliers and Public Debt Dynamics, Consolidations. European Economy Economic Paper No. 460. (2012) and Gianluca Cafiso, Roberto Cellini, Fiscal consolidations for debt-to-GDP ratio containment? Maybe ... but with much care, voxeu.org/ article/fiscal-consolidations-debt-gdp-containment (accessed 20 March 2012). https://

10 Treaty on the Functioning of the European Union, Article 126

doi.org/10.1007/978-88-470-5331-1_12

11 Constitution of Lithuania, Article 128.

12 Constitution of Poland, Article 216.

13 Fundamental Law of Hungary, Articles 36 and 37.

14 Alejandro Guerson, The Composition of Fiscal Consolidation Matters: Policy Simulations for Hungary. IMF Working Paper (Fiscal Affairs Department, 2013). https://doi.org/10.5089/9781484305225.001

15 Kenneth Davey (ed.), Local Government in Critical Times: Policies for Crisis, Recovery and a Sustainable Future. (Council of Europe, 2011).

16 Local Government Financial Management Act, www.riigiteataja.ee/en/eli/523052014001/consolide (accessed 8 June 2018)

17 OECD: Estonia - subnational government country profile. 2017, 2.

18 OECD: Latvia - subnational government country profile. 2017, 2.

19 Gergő Medve-Bálint, Dorothee Bohle, Local Government Debt and EU Funds in the Eastern Member States: The Cases of Hungary and Poland. MaXCaP Working Paper Series, 18 (2016).

20 OECD: Poland - subnational government country profile. 2017, 2.

21 The Fundamental Law of Hungary Article 34 (5), Act CXCIV of 2011 on the economic stability of Hungary Article 10-10/D and 353/2011. (XII.30.) Government decree on the detailed rules for the consent to debt-generating transactions.

22 (1st phase) 2011: 20 county local governments, (2nd phase) 2012: 1,740 local governments under 5,000 inhabitants and multi-purpose co-operations, (3rd phase) 2013: 279 local governments above 5,000 inhabitants, (4th phase) 2014: 516 local governments and co-operations

23 Erika Steiner, Introduction to the Hungarian Local Government System. Hungarian Association of Local Governments - Norway Grants, 2016, 14.

24 OECD: Slovenia - subnational government country profile. 2017, 2.

25 OECD: Czech Republic - subnational government country profile. 2017, 2. 
